\title{
Releasing Dependency on Western Culture in Efforts to Contextualize Christian Theology and Education in Asia
}

\author{
Yudhy Sanjaya, ${ }^{1}$ Rikardo Butar-Butar, ${ }^{2}$ Septerianus Waruwu ${ }^{3}$ \\ Theology Study Program, Real Theological Seminary Batam \\ Christian Education Study Program, Real Theological Seminary Batam \\ Theology Study Program, STT Soteria, Purwokerto \\ yudhysan.real@gmail.com
}

\begin{abstract}
Contextualization in theology is an interesting thing to observe because the development of theology cannot be separated from culture. And nowadays western thoughts greatly influence theology in the world, including in Asia. This is due to the large number of theologians from parts of the western world who pour their main thoughts in books that are made into literature by theologians today in theology and in the world of Christian education. This paper tries to look from a different perspective where Christian theology and education should be based on the culture that has developed in Asian society. It is hoped that the ideas of local theologians will emerge who have influenced the development of theology in Asia. Through the method of studying literature from Asian theologians and observing the phenomena that occur, the writer tries to give the idea that in doing theology and developing Christian education it is necessary to explore Asian local wisdom and release the dependence on Western theology.

Keywords: Contextualization, theology, education, Christianity, Asia
\end{abstract}

\section{INTRODUCTION}

Kosuke Koyama in the foreword of the book Theology of Asia by Douglas J. Elwood asks a reflexive question about the effort to know Jesus personally. When Jesus once asked 'people say, who is the Son of man ... But what do you say, who am I? (Matthew 16: 13,15). According to Koyama, this question needs to be answered by Christians in the development of theology. ${ }^{1}$ Theologians need to answer these questions in theological findings that develop in the cultural sphere in which the theologian resides. Theology rooted in local situations. Theological studies that developed in Asia cannot but be greatly influenced by Western thought and culture. This is because references and literature in Christian educational books as well as theology come from Western theologians. The contributions of Asian theologians have mostly been in the form of rewriting

1 Douglas J. Elwood, Teologi Kristen Asia Tema-Tema Yang Tampil Ke Permukaan (Jakarta: BPK Gunung Mulia, 1993). 
Western theology. ${ }^{2}$ There is a need for the independent thinking of Asian theologians. As expressed by Charles Germany in his review of Protestant theology in Japan, he said that the time had come for the church in Japan to have entered the process of incarnation in Japanese society itself. And Paul Schiling writes about Southeast Asian theologians that creative power and openness are needed in the development of new insights based on their own uniqueness. ${ }^{3}$

\section{Contextual Theology}

Douglas J. Elwood in his book Asian Christian Theology defines the word contextualization as the ability to give meaningful responses to the gospel in the midst of its own condition. Which this expression is based on the definition of contextualization according to TEF, Theological Education Fund. The TEF emphasizes the need to let this gospel take root in the particular environment in which the gospel is proclaimed. ${ }^{4}$ The contextualisas of theological education in third world countries became the context for the discussion in the TEF discussion. ${ }^{5}$ Although it is realized that the idea of contextualization itself has existed long before the TEF trial, which is written in the Bible. Theologians argue that contextualization is only a substitute term for the terms indigenization, inculturation, accommodation and adaptation. There needs to be an understanding among theologians about what things can be contextualized. The contextualization of the Bible, what is the theology or the gospel message? Likewise, the contextualization process can be carried out. Is it only form or only content or or both can be contextualized? ${ }^{6}$

Contextualization of theology is not syncretism, accommodation or situational theology. But contextual theology is Bible-oriented theology. The definitions of syncretism, accommodation and situational theology will provide clarity about what contextualization really means. ${ }^{7}$ Syncretism is a process of integrating one religious element into another that can change the fundamentals of that religion. Syncretism combines two or more opposing beliefs and produces something new. Accommodation means the unchanging process of transmitting

\footnotetext{
2 Ibid.

${ }^{3} \mathrm{lbid}$.

${ }^{4}$ Douglas J. Elwood, Teologi Kristen Asia (Jakarta: BPK Gunung Mulia, 2006). hal

${ }^{5}$ TEF pertama kali dimunculkan pada Ghana Assembly of the International Mis- sionary Council. Sidang ini membahas isu yang berkaitan dengan pendidikan teologi (Ministry in Context: The Third Mandate Programme of the Theological Education Fund (1970-1977) [Written and edited by Theological Education Fund Staff; Bromley, England: Theological Education Fund, 1972])

${ }^{6}$ Rahmiati Tanudjaja, "Kontekstualisasi Sebagai Sebuah Strategi Dalam Menjalankan Misi : Sebuah Ulasan Literatur," Veritas : Jurnal Teologi dan Pelayanan 1, no. 1 (2000): 19-27.

${ }^{7} \mathrm{lbid}$.
} 
Western theology to Christian churches in other parts of the world. And Situational means that the biblical text should not be determined by social context. ${ }^{8}$

It can be concluded that contextual theology is a process that strives for the gospel to be accepted and understood by the recipient in a dynamic cultural existence, from various dimensions both economically, socially, and politically. Contextualization is used as an effort to answer certain cultural adaptations with Bible truth without polluting the truth itself.

\section{Relevance of Theology and Anthropology}

Luzbetak states that cultural anthropology is knowledge that theologians need to master. Anthropology helps theologians or missiologists to understand well the culture they have and also understand the culture of others. Cultural context is the basic equipment that a missiologist must have in carrying out his mission.

Culture becomes part of the social knowledge of a particular society, where in everyday life problems arise that need to be overcome by that community. E. T. Hall argues that culture hides more than it seems. And what is hidden is an effective part of being hidden from that culture. ${ }^{9}$ It can be said that culture is an implicit system of rules of knowledge and behavior. Anthropological consensus lies in the fact that the basis of culture is ideational. The essence of culture is its ideology or point of view and not visible patterns of behavior. ${ }^{10}$

\section{Contextualization of Christian Education}

Christian education in Asia cannot be separated from the influence of Western or European culture. This reality can be seen clearly from the practice, character, system, philosophy to Christian education methods that exist in Asia. The strong influence of the Christian education culture from the West caused the development of Asian Christian education to experience a slowdown. This is because the culture of the Asian and European societies is much different. "In general, European society is known as clan society, and in Asia it is a tribal society." "Likewise in Christian education. Asian theology sees Western theology as irrelevant and unsatisfactory. "Because Christian education and theology are intellectualistic and so on. Christian education and the gospel are also seen as Western features in their delivery. So that the color and educational identity of the Asian people is not visible. Asians no longer have the freedom to express their faith in themselves." 12

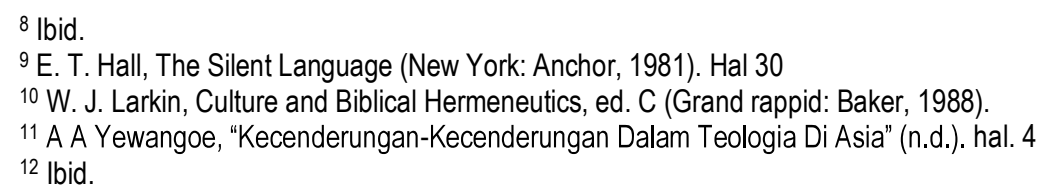


Christian education in the Asian context needs to be colored according to the features of the pluralistic Asian society. Asia is a place or region with plurality or plurality, namely the continent with the most densely populated world with a diversity of cultures, languages, ethnic groups and religions." 13 The diversity of cultures, cultures, ethnicities, races, languages and religions in Asia requires methods, educational systems, methods and styles of Christian education that are in accordance with the colors and colors of a pluralistic Asian society. So that Christian truth values are more easily absorbed by the Asian community because they are carried out according to the multi-cultural character of Asian society.

The need for Christian education in accordance with the Asian context is very urgent today, "due to the fact that in a span of nearly two thousand years, the images and teachings of Jesus which are believed by Asian Christians are tightly wrapped in the frame and formulation of Western christology so that the understanding is complete. about Christ is not fully understood in the context of Jesus living and working." "14 Therefore Christian understanding and education in Asian society is not comprehensive, because it is conveyed in a Western style and color. "As a result, the belief in the faith in Jesus is not deeply rooted, even feels foreign to Asian Christians because it is not born out of His encounter with the Asian world and tends to separate the Asian Christian community from its own historical and socio-cultural context."15

The contextualization of Christian education in Asian society is actually not that difficult, because the historical context of the birth of Christianity and the center of the preaching of the Christian faith, namely the Lord Jesus Christ, is closely related to Asian society. The New Testament and Paul's ministry in the early centuries of the development of Christianity, the Asian region has got a place for the development of Christian education. This is related to the presence of people from Asia at Pentecost. (Acts 2: 9). Even in the course of the ministry of the Apostle Paul it is said that "all the inhabitants of Asia heard and the word of God, whether they were Asians as well as Jews or Greeks as a result of Palus' two years of ministry. (Acts 19;10).

Departing from these facts, Christian religious education which is in line with the thoughts, culture, culture, and colors of the multicultural Asian society needs to be developed immediately so that it is free from the shadows of the influence of western Christian education culture. The continent of Asia as the residence of approximately two thirds of the earth's population needs to be illuminated with Christian education. The Asian continent as the continent with the

${ }^{13}$ Hope S. Antone, Pendidikan Kristiani Kontekstual (Jakarta: PT. BPK Gunung Mulia, 2010). Hal, 8

${ }^{14}$ Alfonsus Ara, "Upaya Mencari Gambaran Yesus Yang Bersifat Ke Asia An," LOGOS (Jurnal

Filsafat - Teologi) 8, no. 2 (2011). Hal, 40

15 Ibid. hal, 41 
largest and most diverse population, the potential problems that arise are also very diverse. Therefore, "Theological thinking and modern Christian education in Asia related to the economic, social, and political situation in Asia, which is still experiencing poverty, underdevelopment, and oppression from the rulers, is something very urgent to do."16

Efforts to contextualize Christian education that have been pursued since the birth of Christianity and the establishment of the church in Asia, until now require full concentration. The contextuality of Christian education in Asia is different from western Christian education. The diversity of ethnic groups, races and religions in Asia is a challenge in itself so that contextualization efforts must be managed as well as possible so that it can be accepted by Asian people who live and live side by side with many religions, ethnic groups and languages.

\section{METHOD}

The author uses the literature study method by paying attention to the opinions of previous researchers written in books and journals related to the topics discussed in this article.

\section{RESULTS AND DISCUSSION}

\section{Exploring Asian Local Wisdom in Theology}

The development of Christian theology and education in Asia cannot be separated from the presence of Asian theologians who dare to bring up their ideas and introduce them in their writings. The author raises this opportunity that there are several Asian theologians with their thoughts that are adapted to Asian local wisdom.

Some names such as Choan Seng Song from Taiwan, Kosuke Koyama from Japan, Hope S, Antone from the Philippines, Eka Darmaputra and Emanuel Gerit Singgih from Indonesia, they are known for their contextual thinking in theology. Choang Seng Song or also known as C. S. Song is one of the contextual theologians in Asia. ${ }^{17} \mathrm{He}$ understands that the theology that has been taught and developed by churches in Asia does not touch local culture, according to him theology should touch the context. ${ }^{18}$ Kosuke Koyama is one of the theologians who developed contextual theology in Japan. ${ }^{19}$ One of the contextual theologies

\footnotetext{
${ }^{16}$ M Darojat Ariyanto, "Teologi Kristen Modern Di Asia" 23, no. 1 (2011): 68-101.

17 "Teologi Kontekstual," Wikipedia, accessed August 15, 2018, https://id.wikipedia.org/wiki/Teologi_kontekstual.

${ }^{18}$ Choang Seng Song, The Compassionate God (New York: Orbis Books, 1982).

19 "Teologi Kontekstual."
} 
that he developed was the Buffalo Theology. ${ }^{20}$ Hope S. Antone is a theologian from the Philippines. He developed contextual theology with a Christian educational approach. ${ }^{21} \mathrm{He}$ understands that the Philippines has its own theology of the culture in the country. This was triggered by the domination of Western theology which was considered to ignore the context of Philippine society. Indonesian theologian Eka Darmaputra ${ }^{22}$ quite influential in contextual theology in Indonesia. He developed theology in the study of Pancasila. ${ }^{23}$ And Emanuel Gerit Singgih is one of the Old Testament theologians in Indonesia. He also developed contextual theology in Indonesia. He is also a lecturer at the Theology Faculty, Duta Wacana Christian University (UKDW). One of his books is entitled Ber theology in Context. ${ }^{24}$

In this article the author does not cover all the thoughts of these Asian theologians. Only one of them represents contextual thinking based on local wisdom in Asia. The author will discuss the thoughts of C.S. Song in theology in Asia.

\section{Choan Seng Song's thoughts in Asian Theology}

The theologian from Taiwan, named Choan-Seng Song, was born in 1929. ${ }^{25}$ Choan went to migrate to National Taiwan University and continued his studies at New College in Edinburgh and Union Theological Seminary in New York. Then Choan worked as a professor in the field of theology and Asian cultures at the Pacific School of Religion, Berkeley, California, USA and worked at the World Alliance of Reformed Churches in Geneva. ${ }^{26}$ Choan is one of the pioneers of Asian theology, with a distinctive style and using references that come from Asia itself. Many of Choan's writings are used by theologians to support their thoughts about the God they believe in

Theology is a reflection or appreciation and recognition of a person towards Allah whom he worships. ${ }^{27}$ It is the same thing that Choan did when he talked about the God he worshiped and knew all this time. Choan's thought in theology in the Asian context is based on his understanding of Western theology. Choan has a different view from western theology with Asian nuances and can be

\footnotetext{
${ }^{20}$ Kosuke Koyama, Water Buffalo Theology (New York: Orbis Books, 2009).

21 "Teologi Kontekstual."

22 Darmaputra dikenal sebagai teolog yang memajukan pemikiran teologi di Indonesia. la sempat menjabat sebagai ketua GMKI (Gerakan Mahasiswa Kristen Indonesia.

23 "Teologi Kontekstual."

24 Ibid.

${ }^{25}$ Elwood, Teologi Kristen Asia Tema-Tema Yang Tampil Ke Permukaan. XXI

${ }^{26}$ I Stevri Lumintang, Teologia Abu-Abu Pluralisme Agama (Malang: Gandum Mas, 2004). 295

${ }^{27}$. https://luxveritatis7.wordpress.com/2016/02/03/berteologi-adalah-mengenal-dan-mengasihi-allah/
} 
understood by Asians. ${ }^{28}$ Meanwhile, Western theology talks about God in accordance with the Western context known to the believers there, because the God whom Asians believe is the same God that the West God believes.

One of the most popular Choan theologies is Transpositional theology. Choan said that the history of Christianity is a continuation of the history of the Israelites and the history of the church just to tell about salvation is wrong. ${ }^{29}$ For Choan, the history of the salvation of the Israeli nation and the church is a symbol of the salvation of all other nations. The theologies that existed in the past need to be contextualized today. Theologies in ancient times were written to answer the problems of the time. Therefore there needs to be a theology that is made to answer problems in the present. With the development of existing theology, Choan is one of the figures of Asian theology who has a different view from Western theology. Choan built theology based on local wisdom, especially Asia. Theological trends in Asia in these times can perhaps be suppressed as attempts to acquire one's own identity, that is, attempts to get out of the legacies that have existed. The past "tendencies ..." which are not favorable, and at the same time show solidarity with the peoples of Asia, depart from and stand firm in the Asian world itself. What is meant is to what extent the churches in their theological endeavors seriously take all the struggles and hopes of Asia, as has been argued above, as their theological point of departure and aim at the same time. That is what Pieris refers to as poverty and diversity.

\section{Application of Christian Education Appropriate Asian Context}

The contextualization of Christian education in Asia has its own challenges and levels of complexity. Efforts to contextualise Christian education have been carried out for a long time, but these efforts must be continued considering the large population of Asia, the large number of religions and beliefs that exist, the number of ethnicities, races, cultures and nations in Asia. In connection with this fact, Christian religious education in Asia, its contextualization is applied in accordance with the culture and culture of the multicultural Asian society.

The challenges of the contextualization of Christian education in Asia today must answer the many realities of life in Asian society. "Asia is currently a place and a region that has many problems and conflicts, namely problems of introversion, hatred, poverty, inequality and violence. ${ }^{30}$ Apart from that, several other problems are. "Aspects of religious issues related to ignorance of religion and the teachings of other faiths, intolerance and suspicion of religions amid complex

${ }^{28}$ Choan-Seng Song, Allah Yang Turut Menderita (Jakarta: Gunung Mulia, 1995). 31

29 Song, Allah Yang Turut Menderita. 31

${ }^{30}$ Antone, Pendidikan Kristiani Kontekstual. Hal 6 
realities". ${ }^{31}$ Therefore, the contextualization of Christian education must pay attention to and accommodate the values of the socio-cultural life of the community that are in accordance with the character of Asian society.

\section{Christian Education Curriculum Asian Context}

Realizing Christian education in the frame of an Asian context begins with the application of a curricula based on a diverse Asian culture. Education as a ministry dimension is structured in an Asian context but still based on the Bible. The Bible contains accurate and sufficient data to prepare a culture-based curriculum for Asian people. The basic thinking related to the New Testament and Christian Education, is as expressed by Boehlke, that "the New Testament as a whole is the first curriculum compiled by the Church to cultivate himself and anyone who feels attracted by His message". ${ }^{32}$

In the Asian context the Christian education curriculum is built according to the Bible's mandate but in accordance with the character and culture of the majority of Asian societies. The values contained in the Christian education curriculum such as mutual cooperation are the pulse of the Christian education curriculum. The western curriculum is based on cognition, combined in accordance with Asian customs. Gotong royong-based Christian Education curriculum will foster a love for the truth of God's Word because Christian education is close and familiar to Asian society. And the spirit of building a mutual cooperation-based curriculum is also in line with the truth of the word of God which says that everyone must help in bearing the burdens that exist, so that the value of Christian truth will be realized. (Galatians 6: 2).

\section{Christian Education Embodies tolerance.}

Asia is a continent and a place where two thirds of the earth's population live. The very large population of ethnic groups, nations, races, languages and religions poses a major challenge to education in Asia. Poverty, ignorance and other social problems are piles of homework which require very urgent. Growing up in the midst of diversity and having a history of being colonized by other nations, inherited suspicion and an attitude of religious exclusivism. So that the practice of intolerance and conflict that smells of SARA is easily ignited.

Christian education as a torch is designed with educational content ranging from planning, philosophy, strategy and implementation to respect and uphold the value of tolerance. Christian education, both in the church and in

${ }^{31} \mathrm{lbid}$.

32 Robert R Boehlke, Sejarah Perkembangan Pikiran Dan Praktek Pendidikan Agama Kristen Dari Plato Sampai Ig. Loyola (Jakarta: PT. BPK Gunung Mulia, 2005). Hal, 71 
schools, is the pioneer in raising awareness that each person is a generation who lives in the context of a plural society. Teaching and the value of tolerance have a special place in Christian education in Asia. Christian education is designed to instill a value of tolerance. Christian education that will be implemented is built with a spirit of brotherhood, accepting one another. Living in a practice and lifestyle that is able to accept diversity.

Christian education is built by prioritizing values and tolerance. Education should not be held to show the weakness of another sect or religion. In learning, teaching about other religions does not sow the seeds of Christian conflict compared to other religions. An approach like this will help the learning system to see sharply the uniqueness of the Christian faith and at the same time learn from the perspective of other faiths so that they will have a clear identity and commitment to their faith as well as build positive relationships with people of other faiths without sacrificing each other. . The important point is to educate them not only to memorize the principles of their faith, but also to be able to see other sects or religions objectively without being influenced. ${ }^{33}$

Christian education in the Asian context must be free from the shadows of blind and intolerant exclusivism. For that Christian education in the context of plural society life must be based on the values of tolerance and respect for religions and the teachings of other religions and beliefs. The practice of respecting the beliefs of other religions does not contradict the values of the teachings of the Lord Jesus as the basis and benchmark of Christian education. In Christian education among other religious communities, Christians must avoid exclusive attitudes and actions. This does not mean that just because they want to be liked or accepted by the existing community, their Christian faith identity is neglected. Christian education must be oriented to the values of the life and teachings of the Lord Jesus, who wants Christians to become salt and light everywhere for anyone, wherever they are. (Matthew 5: 13-16). Even more than that, Christian education in its application in the midst of a multicultural Asian society is guided by the teachings of the Lord Jesus which requires loving all people, including other people who are hostile to believers. (Matthew 5: 43-48).

Tolerance and an attitude of respect and respect for the teachings of other religions and beliefs must be the life of the delivery of Christian education that is relevant for Asian society. Thus the truth value of Christian education can be accepted by various faith groups outside of Christianity. This means that in the practice of social life in a pluralistic community, working together, building

${ }^{33}$ Manggeng Marthin, "Pendidikan Agama Kristen Dalam Masyarakat Majemuk.," Jurnal Intim Teologi Kontekstulasasi (2005). 
positive relationships, and respecting the differences between layers of society are important. However, in this relationship, it shows and practices Christian identity and holds on to the main doctrines and Christian truth values which absolutely must be practiced. Thus Christians can become members of the church with Christian identity and Christ character, who live to love people of other faiths. So that the truth value in the core of Christian education has a place and is accepted by other communities. Suspicion of the issue of Christianization will be avoided and Christian faith can coexist in the frame of love and mutual respect with any religion and belief.

Christian religious education is related to a multi-cultural society. Christian education must also be applied with an approach using the traditional cultures of the surrounding community as a means of implementing Christian education. Claiming that traditional culture is unholy and contrary to Bible truth must be studied, selected and exercised with extreme care. Local cultural practices that contradict the truth must be addressed wisely. Thus, the application of Christian education that is appropriate to the Asian context can be carried out well, without causing other problems.

\section{CONCLUSION}

Approximately two-thirds of the earth's population lives in Asia, which also has a very rich diversity of cultures, ethnicities, religions, languages and nations. The wealth of a multicultural Asian society is not matched by independence in many aspects. In particular, the fields of Asian Christian theology and education are still in the shadow of western cultural influences. Therefore, the contextualization of Christian theology and education which is in harmony with the style and character of Asian society needs continuous maximum efforts so that the views of Christian theology and education are understood, accepted and applied not in a western frame. Efforts to build a Christian theology and education perspective have been pioneered by many figures of Christian theology and education. Choan Seng Song, Kosuke Koyama, Emmanuel Gerrit Singgih, Hope S Antone and many other figures have paved the way towards self-reliance in theological thought and Christian education in the Asian context so that the shadows of western cultural influence can be released.

Choan Seng Song with his transposition theology stated that Christian theology about the continuity of Israel's history and the history of the church in the history of salvation is wrong. For Choan, the history of the salvation of the Israeli nation and the church is a symbol of the salvation of all other nations. Theology must be constructed in an Asian context that is different from western culture. Likewise with Christian education, both its philosophy, psychology, curriculum, 
methods and approaches of Christian education in the frame of the character of Asian society are far different from the character and culture of the West. Christian education in the frame of the character of Asian society must be built according to the culture and character of the multicultural Asian community. A frame of Christian education that is relevant to the Asian context must be realized by developing a curriculum that is in line with the practices of Asian cultural life. Christian education curriculum based on local culture and culture so that Christian values are familiar to their society. Biblical practices and thoughts about Christian education are contained in an acceptable curriculum according to local conditions. Next, Christian education is designed to answer the problems of Asian society who are at risk with conflict and intolerance. Christian education is a pioneer of tolerance. Tolerance, mutual respect, mutual respect for all people with their respective ethnicities, religious cultures and beliefs - each of which has the main portion and emphasis in Christian religious education.

\section{BIBLIOGRAPHY}

Antone, Hope S. Pendidikan Kristiani Kontekstual. Jakarta: PT. BPK Gunung Mulia, 2010.

Ara, Alfonsus. "Upaya Mencari Gambaran Yesus Yang Bersifat Ke Asia An." LOGOS (Jurnal Filsafat - Teologi) 8, no. 2 (2011).

Ariyanto, M Darojat. "Teologi Kristen Modern Di Asia" 23, no. 1 (2011): 68-101.

Boehlke, Robert R. Sejarah Perkembangan Pikiran Dan Praktek Pendidikan Agama Kristen Dari Plato Sampai Ig. Loyola. Jakarta: PT. BPK Gunung Mulia, 2005.

Elwood, Douglas J. Teologi Kristen Asia. Jakarta: BPK Gunung Mulia, 2006.

- Teologi Kristen Asia Tema-Tema Yang Tampil Ke Permukaan. Jakarta: BPK Gunung Mulia, 1993.

Hall, E. T. The Silent Language. New York: Anchor, 1981.

Larkin, W. J. Culture and Biblical Hermeneutics. Edited by C. Grand rappid: Baker, 1988.

Lumintang, I Stevri. Teologia Abu-Abu Pluralisme Agama. Malang: Gandum Mas, 2004.

Marthin, Manggeng. "Pendidikan Agama Kristen Dalam Masyarakat Majemuk." Jurnal Intim -Teologi Kontekstulasasi (2005).

Song, Choan-Seng. Allah Yang Turut Menderita. Jakarta: Gunung Mulia, 1995.

Tanudjaja, Rahmiati. "Kontekstualisasi Sebagai Sebuah Strategi Dalam Menjalankan Misi : Sebuah Ulasan Literatur." Veritas : Jurnal Teologi dan Pelayanan 1, no. 1 (2000): 19-27.

Yahya, Pancha W. "Tinjauan Terhadap Pandangan Choan-Seng Song Mengenai Sejarah Keselamatan (Heilsgeschichte)." Veritas : Jurnal Teologi dan Pelayanan 12, no. 1 (2019): 123-134.

Yewangoe, A A. "Kecenderungan-Kecenderungan Dalam Teologia Di Asia" (n.d.). 